\title{
Risk factors associated with BoHV-1 and BVDV seropositivity in buffaloes (Bubalus bubalis) from the State of Paraiba, Northeastern Brazil
}

\section{Fatores de risco associados com as soropositividades para BoHV-1 e BVDV em búfalos (Bubalus bubalis) no Estado da Paraíba, Nordeste do Brasil}

\author{
Leise Gomes Fernandes ${ }^{1}$; Carla Lauise Rodrigues Menezes Pimenta ${ }^{1}$; Edviges \\ Maristela Pituco²; Arthur Willian de Lima Brasili1; Sérgio Santos de Azevedo ${ }^{3 *}$
}

\begin{abstract}
This study aimed to identify the risk factors associated with Bovine Herpesvirus Type 1 (BoHV-1) and Bovine Viral Diarrhea Virus (BVDV) infections in buffaloes in the State of Paraíba, Northeastern Brazil, using 136 female buffaloes $\geq 24$ months old from 14 herds. For the serological diagnosis of the BoHV-1 and BVDV infections, the virus-neutralization test $(\mathrm{VN})$ was used and in each herd, an epidemiological questionnaire was applied in order to obtain data to be used in the risk factor analysis. Of the 136 animals $86(63.2 \%)$ were positive for BoHV-1 and $12(8.8 \%)$ for BVDV. The presence of watering points (odds ratio $=17.68 ; 95 \% \mathrm{CI}=3.74-83.04$ ) was identified as risk factor for $\mathrm{BoHv}-1$, and animal purchasing was a risk factor for both BoHV-1 (odds ratio $=68.64 ; 95 \% \mathrm{CI}=12.28-383.73$ ) and BVDV (odds ratio $=3.64 ; 95 \% \mathrm{CI}=1.04-12.76$ ). The results from the present study showed an evidence of the presence of BoHV-1 and BVDV infections in buffaloes from the State of Paraíba, Northeastern Brazil. It is suggested that control and prevention measures should be adopted, such as the use of diagnostic tests prior to animal purchasing and the use of vaccines to avoid the introduction of infected animals into the herds and the consequent dissemination of the infections, minimizing economic losses.
\end{abstract}

Key words: BoHV-1. BVDV. Buffaloes. Northeastern Brazil. Risk factors. Serology.

\section{Resumo}

Este estudo teve como objetivo identificar os fatores de risco associados à infecções pelo Herpesvírus Bovino Tipo 1 (BoHV-1) e Vírus da Diarreia Viral Bovina (BVDV) em búfalos no Estado da Paraíba, Nordeste do Brasil, utilizando 136 búfalas com idade $\geq 24$ meses procedentes de 14 rebanhos. Para o diagnóstico sorológico das infecções por BoHV-1 e BVDV, empregou-se o teste de virusneutralização (VN) e em cada rebanho foi aplicado questionário epidemiológico para obtenção de dados a serem utilizados na análise de fatores de risco. Dos 136 animais $86(63,2 \%)$ foram positivos para BoHV-1 e $12(8,8 \%)$ para BVDV. Presença de aguadas (odds ratio $=17,68$; IC $95 \%=3,74-83,04$ ) foi identificada como fator de risco para o BoHV-1, e compra de animais foi um fator de risco para BoHV-1 (odds ratio $=68,64$; IC $95 \%=12,28-383,73$ ) e BVDV (odds ratio $=3,64$; IC 95\% $=1,04-12,76$ ). Os resultados do presente estudo evidenciaram a presença das infecções por BoHV-1 e BVDV em búfalos do Estado da Paraíba, Nordeste do Brasil. Sugere-se que que medidas de controle e prevenção sejam adotadas,

\footnotetext{
1 Discentes de Doutorado, Programa de Pós-Graduação em Medicina Veterinária, Universidade Federal de Campina Grande, UFCG, Patos, PB, Brasil. E-mail: leisegf@hotmail.com; carlalauise@hotmail.com; arthurwillian7@yahoo.com.br

2 Pesquisador Científico nível VI, Instituto Biológico de São Paulo, IBSP, São Paulo, SP, Brasil. E-mail: pituco@biologico.sp.gov. br

3 Prof., Programa de Pós-Graduação em Medicina Veterinária, UFCG, Patos, PB, Brasil. E-mail: sergio@vps.fmvz.usp.br Author for correspondence
} 
como o uso de testes de diagnóstico antes da compra de animais e a utilização de vacinas para evitar a introdução de animais infectados nos rebanhos e consequente disseminação das infecções, minimizando perdas econômicas.

Palavras-chave: BoHV-1. BVDV. Búfalos. Nordeste do Brasil. Fatores de risco. Sorologia.

\section{Introduction}

Bubaline presents as distinctive features their rusticity and adaptability to climatic and topographic factors and poor soils, added to the double aptitude for the production of both meat and milk, which make it a good alternative for the production of animal protein, mainly in tropical countries such as Brazil. Currently, Brazil has a prominent position in buffalo rearing and has a headcount of more than a million animals, of which the Northeastern region has about 122 thousand animals (IBGE, 2012). In the State of Paraiba, the bubaline headcount has a total of approximately 933 animals (IBGE, 2012).

Over the past years, with the expansion of the buffalo farming in Brazil, the interest on the sanitary state of these animals has increased, not only due to its importance but also because of the possibility of these animals acting as sources of infection of diseases for bovine and other species (SCHEFFER, 2013). Some infectious diseases can determine reproductive failures and may compromise simultaneously many animals of different categories, causing several clinical signs such as oestrus recurrence, abortions, perinatal mortality, birth of weak animals and infertility, which result in great economic damage (JUNQUEIRA; ALFIERI, 2006). In this context, the infections by the Bovine Herpesvirus Type 1 (BoHV-1) and the Bovine Viral Diarrhea Virus (BVDV) are of importance, and are responsible for the Infectious Bovine Rhinotracheitis/Infectious Pustular Vulvovaginitis (IBR/IPV) and Bovine Viral Diarrhea/Mucosal Disease (BVD/MD), respectively.

BoHV-1 is an important bovine pathogen, causing significant economic losses related to failures in the reproduction and an increase of the mortality in the herds (CORTEZ et al., 2001). BoHV-1 has been reported to adapt itself to other species (THIRY et al., 2006) and the buffaloes' susceptibility has been demonstrated both in isolation and in viral identification, as in serological studies (SCICLUNA et al., 2010; MONTAGNARO et al., 2014). BVDV has a worldwide distribution and is endemic in the majority of the bovine populations, causing economic losses mainly of reproductive origin (GIRALDO et al., 2013). One of the most important characteristics of this virus is its high mutation frequency and the tendency to recombine, leading to various clinical manifestations and the difficulty to control the disease (VARGAS et al., 2009).

Considering the lack of epidemiological studies on BoHV-1 and BVDV in buffaloes in the State of Paraiba, Northeastern Brazil, this study aimed to identify the risk factors associated with seropositivity for BoHV-1 and BVDV in buffaloes.

\section{Materials and Methods}

The study was carried out in 14 herds with buffalo farming in the counties of Alagoa Nova, Areia, Campina Grande, Guarabira, Juripiranga, Santa Helena, Sapé, Rio Tinto, Santana dos Garrotes, Itatuba, Solânea and Cacimbas (Figure 1). The studied population was formed of bubaline females with aptitude for meat and milk, mixed-bred and of the Murrah breed, with age $\geq 24$ months. For the calculation of the number of animals to be sampled, the formula for simple random sampling was used:

$n=\frac{Z^{2} P(1-P)}{d^{2}}$

$\mathrm{n}=$ number of animals to be sampled

$\mathrm{Z}=$ value of normal distribution for the $95 \%$ confidence level

$\mathrm{P}=$ expected prevalence of $50 \%$ (for the maximization of the sample)

$\mathrm{d}=$ error of $10 \%$ 
Figure 1. Geographical distribution of the counties used in the State of Paraíba, Northeastern Brazil. Detail shows the State of Paraíba into Brazil.

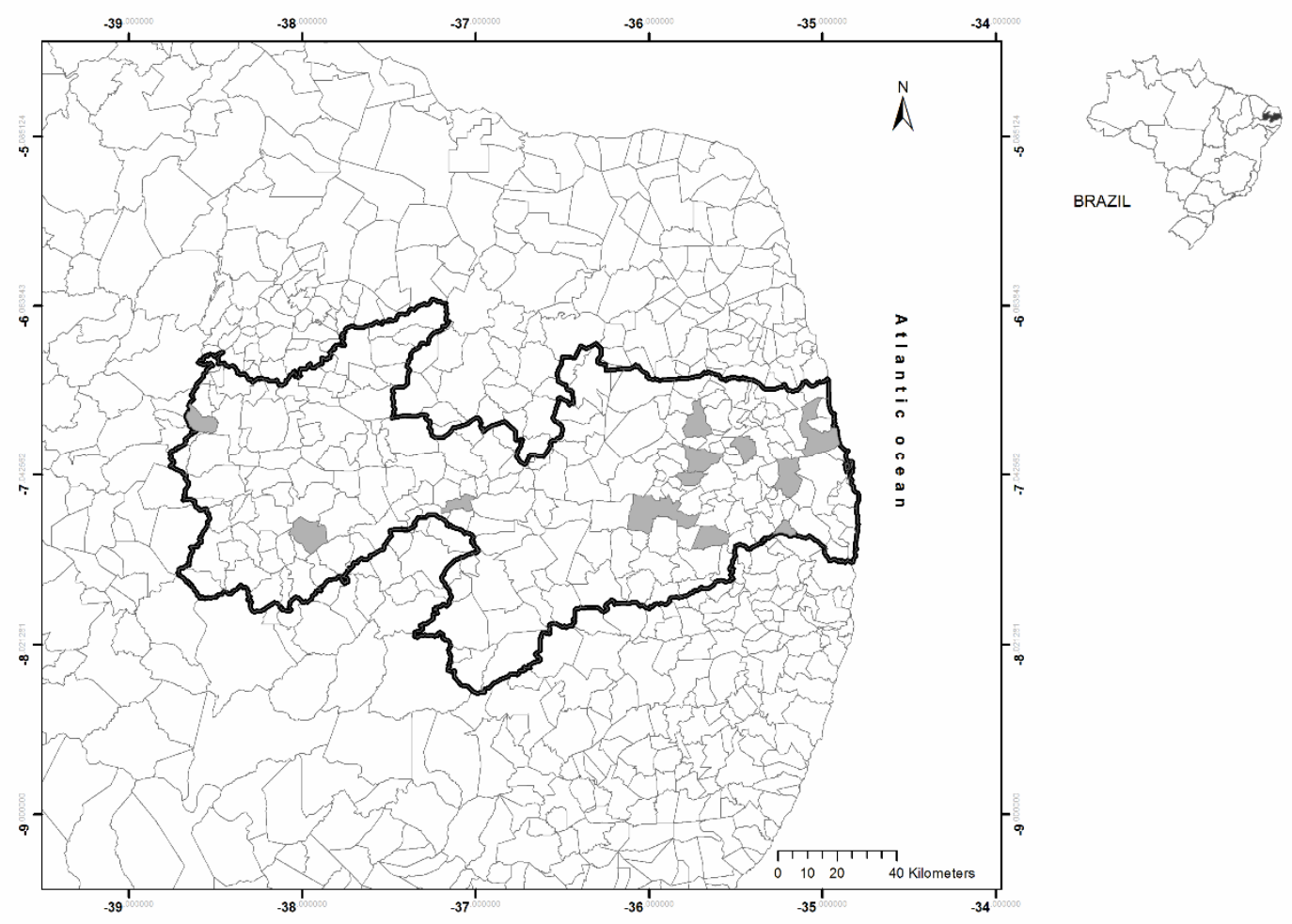

In total, 136 bubaline females with age $\geq 24$ months were selected from 14 herds. Blood samples were collected in the period from November 2012 to July 2013, by venipuncture of the jugular with disposable needle and a tube with vacuum (without anti-coagulant) with capacity for $15 \mathrm{ml}$. During blood collection, an epidemiological questionnaire was applied in order to obtain data to be used in the risk factor analysis. The variables and respective categories used were: management system (intensive, semi-intensive, extensive), type of exploration (meat, milk or mixed), type of milking (manual, mechanical), number of milking per day (non-milking, once a day, twice a day), presence of other animal species (bovine, equine, goats/sheep, swine, poultry, dog, cat), presence of wildlife (no, yes), occurrence of miscarriages during the last 12 months (no, yes), presence of rodents (no, yes), rodent control (no, yes), feeding on native pasture (no, yes), water source (drinking troughs, watering points), animal purchasing (no, yes), pasture rental (no, yes), presence of flooded areas (no, yes), presence of maternity pens (no, yes), separation of young from adults animals (no, yes), and presence of veterinary assistance (no, yes).

For the serological diagnosis of BoHV-1 and BVDV infections the virus-neutralization technique was used (OIE, 2008, 2010). The cytopathic viral strains BoHV-1 e BVDV-1 (NADL), supplied by the Virology Institute of the Veterinary Medicine College of Hanover, Germany were used. The technique was used in two stages, screening and titration, and a sample was considered to be positive when it presented a titer $\geq 2$ for BoHV-1 and $\geq 10$ for BVDV. The neutralizing antibody titers were considered as being the reciprocal of the higher serum dilutions that inhibited viral replication and the consequent production o cytopathic effect of BVDV and BoHV-1. 
Risk factor analysis was performed in two steps: univariable and multivariable analysis. Univariable analysis was performed using the chi-square test or Fisher's exact test (ZAR, 1999), and those variables that presented $P \leq 0.20$ were used for multivariable logistic regression. The multivariable analysis was then performed, using the stepwise forward method (HOSMER; LEMESHOW, 2000). The significance level in multivariable analysis was $5 \%$. Collinearity among independent variables was assessed using correlation analysis, and when two variables were highly collinear (correlation coefficient $>0.90$ ), only one variable was likely to enter the multivariable analysis, and therefore the selection of which collinear variable to enter the model was guided by biological plausibility (DOHOO et al., 1996). The tests were performed using the SPSS for Windows software package, version 13.0.

\section{Results and Discussion}

Of the 136 buffaloes used $86(63.2 \%)$ and 12 (8.8\%) were seropositive for BoHV-1 and BVDV, respectively. Results of the univariable analysis of risk factors for BoHV-1 and BVDV with the most associated variables $(P \leq 0.20)$ are shown in Table 1 , and in Table 2 are shown the final models of logistic regression analysis for BoHV-1 and BVDV risk factors. Presence of watering points (odds ratio $=17.68 ; 95 \% \mathrm{CI}=3.77-83.04)$ was identified as risk factor for BoHV-1, and animal purchasing was considered a risk factor for both BoHV-1 (odds ratio $=68.64 ; 95 \% \mathrm{CI}=12.28-383.73$ ) and BVDV (odds ratio $=3.64 ; 95 \% \mathrm{CI}=1.04-12.76)$.

The high frequency of seropositivity for BoHV1 found in this study corroborates the results found in recent studies carried out in the Brazilian states of Pará and Amapá (FERREIRA et al., 2009), and in Rio Grande do Sul (SCHEFFER, 2013), with prevalence rates of $82.4 \%$ and $44 \%$, respectively. However, these results indicate that BoHV-1 is broadly disseminated in the region, which reinforces the possibility of these animals acting as sources of infection, mainly when dealing with animals with latent infection, which may disseminate the virus throughout their lives (BEZERRA et al., 2012). For BVDV, the positivity rate found was $8.8 \%$, similar to the results found by Martins et al. (2012) in the State of São Paulo (12.9\%) and Scheffer (2013) in Rio Grande do Sul (10.8\%). However, these results suggest the circulation of BVDV and $\mathrm{BoHV}-1$ within herds in Paraiba and due to the fact that it is common in the region to associate the farming of bovine and bubaline, the bovine-bubaline transmission is possibly being important (SCHEFFER, 2013).

The virus-neutralization technique can be impracticable as a diagnostic method in herds which adopt the vaccination against BoHV-1 and BVDV, since the differentiation of the vaccine antibodies from those produced as a result of the infection is not possible (TAKIUCHI et al., 2001). However, in the State of Paraiba, the vaccination of bubaline against BoHV-1 e BVDV is not a disseminated practice, accordingly this a fact that excludes the possible interference of the serology results. On the other hand, the practice of not vaccinating the animals could justify the high seropositivity rates found.

Animal purchasing was identified as a risk factor for BoHV-1 and BVDV, a similar result found by Dias et al. (2008) in bovine in the State of Paraná, Brazil. Animal purchasing is a classical risk factor associated with infectious diseases, and it suggests the importance of carrying out a sanitary control when purchasing animals by serological diagnosis at the origin and the destiny of the animals, as a way of avoiding the introduction of infected animals into the herds. It is important to highlight that in the State of Paraiba the serological testing for BoHV-1 and BVDV is not a common practice among rural producers. 
Table 1. Results of the univariable analysis of the risk factors for BoHV-1 and BVDV seropositivities in buffaloes in the State of Paraiba, Northeastern Brazil, with the most associated variables $(P \leq 0.20)$.

\begin{tabular}{|c|c|c|c|c|}
\hline Variable & Category & $\begin{array}{c}\text { Total no. of } \\
\text { animals }\end{array}$ & $\begin{array}{l}\text { No. of positive } \\
\text { animals }(\%)\end{array}$ & $P$ \\
\hline \multicolumn{5}{|l|}{ BoHV-1 } \\
\hline \multirow[t]{2}{*}{ Presence of swine } & No & 121 & $72(59.5)$ & \\
\hline & Yes & 15 & $14(93.3)$ & 0.023 \\
\hline \multirow[t]{2}{*}{ Rodent control } & No & 48 & $42(87.5)$ & \\
\hline & Yes & 88 & $44(50)$ & 0.001 \\
\hline \multirow[t]{2}{*}{ Presence of watering points } & No & 58 & $28(48.3)$ & \\
\hline & Yes & 78 & $58(74.4)$ & 0.003 \\
\hline \multirow[t]{2}{*}{ Animal purchasing } & No & 99 & $55(55.6)$ & \\
\hline & Yes & 37 & $31(83.8)$ & 0.005 \\
\hline \multirow[t]{2}{*}{ Presence of flooded areas } & No & 6 & $0(0)$ & \\
\hline & Yes & 130 & $86(66.2)$ & 0.002 \\
\hline \multirow[t]{2}{*}{ Separation of young from adult animals } & No & 87 & $45(51.7)$ & \\
\hline & Yes & 49 & $41(83.7)$ & $<0.001$ \\
\hline \multicolumn{5}{|l|}{ BVDV } \\
\hline \multirow[t]{2}{*}{ Presence of equine } & No & 15 & $3(20)$ & \\
\hline & Yes & 121 & $9(7.4)$ & 0.130 \\
\hline \multirow[t]{2}{*}{ Animal purchasing } & No & 84 & $4(4.8)$ & \\
\hline & Yes & 52 & $8(15.4)$ & 0.058 \\
\hline
\end{tabular}

Table 2. Risk factors for BoHV-1 and BVDV infections in buffaloes in the State of Paraiba, Northeastern Brazil, identified by multiple logistic regression.

\begin{tabular}{lccc}
\hline Variable & Odds ratio & $95 \%$ CI & $P$ \\
\hline BoHV-1 & & & \\
Presence of watering points & 17.68 & {$[3.77-83.04]$} & $<0.001$ \\
Animal purchasing & 68.64 & {$[12.28-383.73]$} & $<0.001$ \\
BVDV & & & \\
Animal purchasing & 3.64 & {$[1.04-12.76]$} & 0.044 \\
\hline
\end{tabular}

The presence of watering points was a risk factor for BoHV-1, which points to the possibility of indirect transmission by the ingestion of contaminated water, once that these animals have the habit of bathing in small mud puddles or watering points and also to urinate and defecate whilst ingesting water in these places. Scicluna et al. (2010) detected the presence of active viral particles in feces of buffaloes positive for BoHV-1, which may represent an elimination route of the agent and a source of environmental contamination. 


\section{Conclusions}

The results from the present study showed an evidence of BoHV-1 and BVDV seropositivity in buffaloes from the State of Paraíba, Northeastern Brazil. It is suggested that control and prevention measures should be adopted, such as the use of diagnostic tests prior to animal purchasing and the use of vaccines to avoid the introduction of infected animals into the herds and the consequent dissemination of the infections, minimizing economic losses.

\section{Acknowledgements}

Conselho Nacional de Desenvolvimento Científico e Tecnológico (CNPq) for finantial support (code 302131/2012-4).

\section{References}

BEZERRA, D. C.; CHAVES, N. P.; SOUSA, V. E.; SANTOS, H. P.; PEREIRA, H. M. Fatores de risco associados à infecção pelo Herpesvírus Bovino Tipo 1 em rebanhos bovinos leiteiros da região amazônica maranhense. Arquivos do Instituto Biológico, São Paulo, v. 79, n. 1, p. 107-111, 2012.

CORTEZ, A.; HEINEMANN, M. B.; ALFIERI, A. F.; MÉDICI, K. C.; ALFIERI, A. F.; OLIVEIRA, D. B.; MEYER, A. D.; SOARES, R. M.; SAKAMOTO, S. M.; AMARAL, R.; BARUSELLI, P. S.; FUJI, T.; RICHTZENHAIN, L. J. Comparação das técnicas de ELISA indireto de soroneutralização da detecção de anticorpos contra o BHV-1 em amostras de soro bubalino (Bubalus bubalis). Brazilian Journal of Veterinary Research and Animal Science, São Paulo, v. 38, n. 3, p. 146-148, 2001.

DIAS, J. A.; ALFIERI, A. A.; MÉDICI, K. C.; FREITAS, J. C.; FERREIRA NETO, J. S.; MÜLLER, E. E. Fatores de risco associados à infecção pelo herpesvírus bovino 1 em rebanhos bovinos da região Oeste do Estado do Paraná. Pesquisa Veterinária Brasileira, Seropédica, v. 28, n. 3, p. 161-168, 2008.

DOHOO, I. R.; DUCROC, C.; FOURICHON, C.; DONALD, A.; HURNIK, D. An overview of techniques for dealing with large numbers of independent variables in epidemiologic studies. Preventive Veterinary Medicine, New York, v. 29, n. 3, p. 221-239, 1996.
FERREIRA, R. N. Prevalência da Rinotraqueite Infecciosa Bovina (IBR) em touros bubalinos em propriedades localizadas no Amapá e Ilha de Marajó (PA), Brasil. 2009. Dissertação (Mestrado em Ciência Animal) - Universidade Federal do Pará, Belém.

GIRALDO, J. L. M.; GARCÍA, I. W.; ABELEDO, M. A. Prevalencia de anticuerpos al virus de la diarrea viral boina, Herpesvirus bovino 1 y Herpesvirus bovino 4 en bovinos y búfalos en el Departamento de Caquetá, Colombia. Revista de Salud Animal, La Habana, v. 35, n. 3, p. 174-181, 2013.

HOSMER, D. W.; LEMESHOW, S. Applied logistic regression. New York: John Wiley \& Sons, 2000. 373 p.

INSTITUTO BRASILEIRO E GEOGRAFIA E ESTATÍSTICA - IBGE. Sistema IBGE de Recuperação Automática - SIDRA. Pesquisa da Pecuária Municipal. Rio de Janeiro: IBGE, 2012. Disponível em: <http:// www.sidra.ibge.gov.br/bda/pecua/default.asp? $\mathrm{t}=2 \& \mathrm{z}$ $=t \& o=24 \& u 1=1 \& u 2=1 \& u 3=1 \& u 4=1 \& u 5=1 \& u 6=1$ $\& u 7=1>$. Acesso em: 11 nov. 2014.

JUNQUEIRA, J. R. C.; ALFIERI, A. A. Falhas na reprodução na pecuária bovina de corte com ênfase para causas infecciosas. Semina: Ciências Agrárias, Londrina, v. 27 , n. 2, p. 289-298, 2006.

MARTINS, M. S. N.; NOGUEIRA, A. H. C.; STEFANO, E.; LIMA, M. S.; COSTA, J. F.; MONTEIRO, B. M.; BIRGEL JUNIOR, E. H.; OKUDA, L. H.; PITUCO, E. M. Infection of buffaloes of the state of São Paulo/Brazil by BoHV-1 and BVD. In: BRAZILIAN CONGRESS OF VIROLOGY \& VII MERCOSUL MEETING OF VIROLOGY, VETERINARY VIROLOGY, 23., 2012, Foz do Iguaçu. Anais... Foz do Iguaçu, 2012. p. 467-468.

MONTAGNARO, S.; MARTINIS, C.; IOVANE, V.; CIARCIA, R.; DAMIANO, S.; NIZZA, S.; MARTINO, L.; IOVANE, G.; PAGNINI, U. Bovine herpesvirus type 1 marker vaccine induces cross-protection against bubaline herpesvirus type 1 in water buffalo. Preventive Veterinary Medicine, New York, v. 116, n. 1-2, p. 56-62, 2014.

SCHEFFER, C. M. Herpesvírus e pestivirus em rebanhos bubalinos do Rio Grande do Sul. 2013. Dissertação (Mestrado em Ciências Veterinárias) - Universidade Federal do Rio Grande do Sul, Porto Alegre.

SCICLUNA, M. T.; CAPRIOLI, A.; SARALLI, G.; MANNA, G.; BARONE, A.; CERSINI, A.; CARDETI, G.; CONDOLEO, R. U.; AUTORINO, G. L. Should the domestic buffalo (Bubalus bubalis) be considered in the epidemiology of bovine herpesvirus 1 infection? Veterinary Microbiology, Amsterdam, v. 143, n. 1, p. 81$88,2010$. 
TAKIUCHI, E.; ALFIERI, A. F.; ALFIERI, A. A. Herpesvírus bovino tipo 1: tópicos sobre a infecção e métodos de diagnóstico. Semina: Ciências Agrárias, Londrina, v. 22, n. 2, p. 203-209, 2001.

THIRY, J.; KEUSER, V.; MUYLKENS, B.; MEURENS, F.; GOGEV, S.; VANDERPLASSCHEN, A.; THIRY, E. Ruminant alphaherpesviruses related to bovine herpesvirus 1. Veterinary Research, London, v. 37, n. 2, p. 169-190, 2006.

VARGAS, D. S.; JAIME, J.; VERA, V. J. Perspectivas para el control del virus de la diarrea viral bovina (BVDV). Revista Colombiana de Ciencias Pecuarias, Medellín, v. 22, n. 4, p. 677-688, 2009.
WORLD ORGANIZATION FOR ANIMAL HEALTH - OIE. Manual of standards for diagnostic tests and vaccines for terrestrial animals. Bovine Viral Diarrhea. Paris: OIE, 2008. Available at: <http://www.oie.int/ fileadmin/Home/eng/Health_standards/tahm/2.04.08_ BVD.pdf.>. Accessed at: 11 nov. 2014.

. Manual of standards for diagnostic tests and vaccines for terrestrial animals. Infectious bovine rhinotracheitis/infectious pustular vulvovaginitis. Paris: OIE, 2010. Available at: <http://www.oie.int/fileadmin/ Home/eng/Health_standards/tahm/2.04.13_IBR_IPV. pdf $>$. Accessed at: $\overline{1} 1$ nov. 2014.

ZAR, J. H. Biostatistical analysis. $4^{\text {th }}$ ed. Upper Saddle River: Prentice Hall, 1999. 663 p. 
